Збірник наукових праць Державного науково-дослідного інституту випробувань і сертифікачії озброєння та військової техніки. 2019. Вип. № 2

ISSN 2706-7386

УДК 629.735 .45

DOI: $10.37701 /$ dndivsovt.2.2019.18

Пилипенко О.І., Колесник Д.М., Березняк А.М., Шоха В.М. Державний науково-дослідний інститут випробувань і сертифікації озброєння та військової техніки

\title{
ВІБРАЦІЙНА НАВАНТАЖЕНІСТЬ ТА РУЙНУВАННЯ ЗУБЧАСТИХ ПЕРЕДАЧ ВЕРТОЛІТНИХ РЕДУКТОРІВ
}

\begin{abstract}
Роглянута вібраційна навантаженість високошвидкісних зубчастих передач вертолітних редукторів на злітному і крейсерському режимах експлуатації, розподіл навантаження між зубиями в зоні багатопарного зачеплення, динамічні навантаження в зачепленні зубчастих коліс та їх пошкоджуваність і руйнування.
\end{abstract}

Ключові слова: зубчасті передачі вертольотних редукторів, вібраційна навантаженість, руйнування.

Постановка проблеми. Сучасний стан найбільш застосовуваних вертольотів Ми-8 різних модифікацій пасажирського, транспортного та військового призначення характеризується тим, що в них $\epsilon$ агрегати 3 обмеженим ресурсом, відмови яких безпосередньо впливають на безпеку польотів.

До таких агрегатів, поза іншими, відносяться такі найбільш навантажені агрегати трансмісії вертольота (АТВ) як головний, проміжний та хвостовий редуктори. Редуктору вертольота встановлюється час гарантованої роботи - ресурс - на основі великого обсягу конструкторських, технологічних і доводочних робіт по усуненню дефектів, а також великої кількості різнорідних випробувань [1].

Оскільки, найближчим часом заміни даному типу вертольотів не очікується, необхідно забезпечити підтримку стану льотної придатності наявного парку вертольотів цього типу. Крім того, виробництво агрегатів для даного типу вертольотів стає все менш доцільним або здійснюється за межами країни і тоді їх вартість досягає нерентабельного рівня.

Таким чином, єдиним виходом з ситуації, яка склалася, $є$ поетапне встановлення i збільшення ресурсів вказаних агрегатів $[2,3,4]$. Для цього необхідні певні дослідження і обсяги випробувань з метою наукового підтвердження можливості встановлення нових і збільшення раніше встановлених ресурсів.

Для обгрунтованого збільшення ресурсу вертольотних редукторів [5] необхідно мати наявні дані по навантаженості їх зубчастих передач на основних режимах польоту, результати стендових випробувань, розрахунків на міцність, витривалість, напруженодеформованого стану і т. і. Наявний обсяг таких даних дуже обмежений, тому виникає необхідність проведення досліджень i спеціальних випробувань для визначення ресурсоздатності АТВ.

В аерокосмічному і військовому застосуванні, де вага відіграє одну з головних ролей [1], системи зубчастих передач проектуються за умов, що суттєво позначаються на їх довговічності. Крім того, зубчасті передачі іноді проектують, застосовуючи статичний аналіз. Проте, коли вони працюють на великих частотах обертання, треба враховувати коливальні процеси, що невідворотно супроводжують їх експлуатацію.

Отримані результати будуть використані в перевірочних розрахунках, випробуваннях відповідних деталей редукторів за різними критеріями і підготовці висновків про доцільність продовження ресурсів трансмісій вертольотів Ми-8 та їх модифікацій.

Аналіз досліджень і публікацій. Про ефективність встановлення і збільшення ресурсів агрегатам трансмісії вертольотів свідчать: оцінка і обгрунтування продовження ресурсу елементів конструкцій у двох томах під редакцією академіка В.Т. Трощенка Інституту проблем міцності НАН України [3], розроблене відповідне положення РФ (2004) [2] та захист дисертації на подібну тему (2014) стосовно вертольотів Ми-2 [4]. 
У більшості раніше проведених робіт дана оцінка навантаженості та напруженодеформованого стану зубчастих передач в основному для однопарного зачеплення зубчастих коліс.

У різних публікаціях, в тому числі закритих, розрізнених відомостях про вібраційний стан зубчастих передач авіаційних редукторів не приділено належної уваги до питань зв'язку між коливальними процесами в редукторах і станом їх деталей.

Мета статті. Розглянути наявні дані по статичних та динамічних навантаженнях в зоні багатопарного зачеплення, наявні дані по таких АТВ Ми-8 як головний, проміжний і хвостовий редуктори та їх зубчасті передачі, виявлення вібраційних навантажень деталей редукторів, їх дефектів та руйнувань.

Виклад основного матеріалу. Одногвинтові вертольоти типу найбільш широко застосовуваних Ми-8 різних модифікацій оснащені головним, проміжним та хвостовим редукторами, які застосовуються для збільшення крутного моменту за рахунок зниження частоти обертання відповідних валів.

Головний редуктор призначений для підсумовування потужності двох газотурбінних двигунів, передаючи іï на вали несучого та рульового гвинтів через трансмісійні вали $\mathrm{i}$ забезпечуючи приводи допоміжних агрегатів. Головний редуктор складається з вхідного і центрального редукторів, лівої і правої коробок приводів, передніх і задніх конічних редукторів, муфт вільного ходу, маслоагрегата, блоку фільтрів, підкосів і шпильок кріплення.

Центральний редуктор являє собою шестеренний агрегат, що здійснює два ступеня редукції і забезпечує привод вала несучого гвинта.

Головний редуктор ВР-8А. Найбільш широко застосовуваним на даний час $\epsilon$ головний редуктор ВР-8А, який призначений для передачі крутного моменту від двигунів до несучого гвинта вертольота, а також для привода агрегатів, встановлених на редукторі.

Зниження частоти обертання в головному редукторі досягається застосуванням трьох ступенів редукції. Перша ступінь являє собою два ведучих циліндричних косозубих колеса, які приводяться в обертання від двигунів і знаходяться в зачепленні з третім, загальним для них веденим зубчастим колесом. Друга ступінь редукції складається 3 двох конічних зубчастих коліс зі спіральними зубцями. Третя ступінь редукції виконана за схемою замкненого диференціального механізму, що складається з диференціала і його замикаючого ланцюга.

Від головного редуктора забезпечується привод ряду агрегатів, робота яких можлива i у випадку відмови силової установки. Кінематична схема редуктора представлена на рис. 1 [6]. Редуктор складається з наступних вузлів: картера, двох муфт вільного ходу, привода вала несучого гвинта, вала несучого гвинта, привода рульового гвинта і приводів агрегатів. Детальний опис взаємодії деталей конструкції редуктора ВР-8А міститься в [6].

На модифіковані транспортні вертольоти Ми-8МТ, Ми-8МТВ і т.п. встановлюються редуктори ВР-14 [7], які були спроектовані спочатку з метою їх застосування на вертольоті Ми-14 для більш впевненого відриву від водної поверхні.

Проміжний редуктор [6] призначений для зміни напряму осі хвостового вала трансмісії на кут $45^{0}$ у відповідності до напряму кінцевої балки. Зміна напряму осі хвостового вала досягається застосуванням в редукторі пари конічних зубчастих коліс 3 однаковою кількістю зубців без зміни частоти обертання ведучого і веденого валів редуктора.

Хвостовий редуктор [6] призначений для привода рульового гвинта 3 необхідною частотою обертання. Передача потужності на рульовий гвинт здійснюється парою конічних коліс зі спіральними зубцями, кут між осями обертання яких дорівнює $90^{\circ}$. Крім того, на хвостовий редуктор встановлюється механізм керування рульовим гвинтом у вигляді роликового ланцюга, перекинутого через зірочку, з метою здійснення зміни кроку гвинтів для забезпечення шляхового керування вертольотом. 


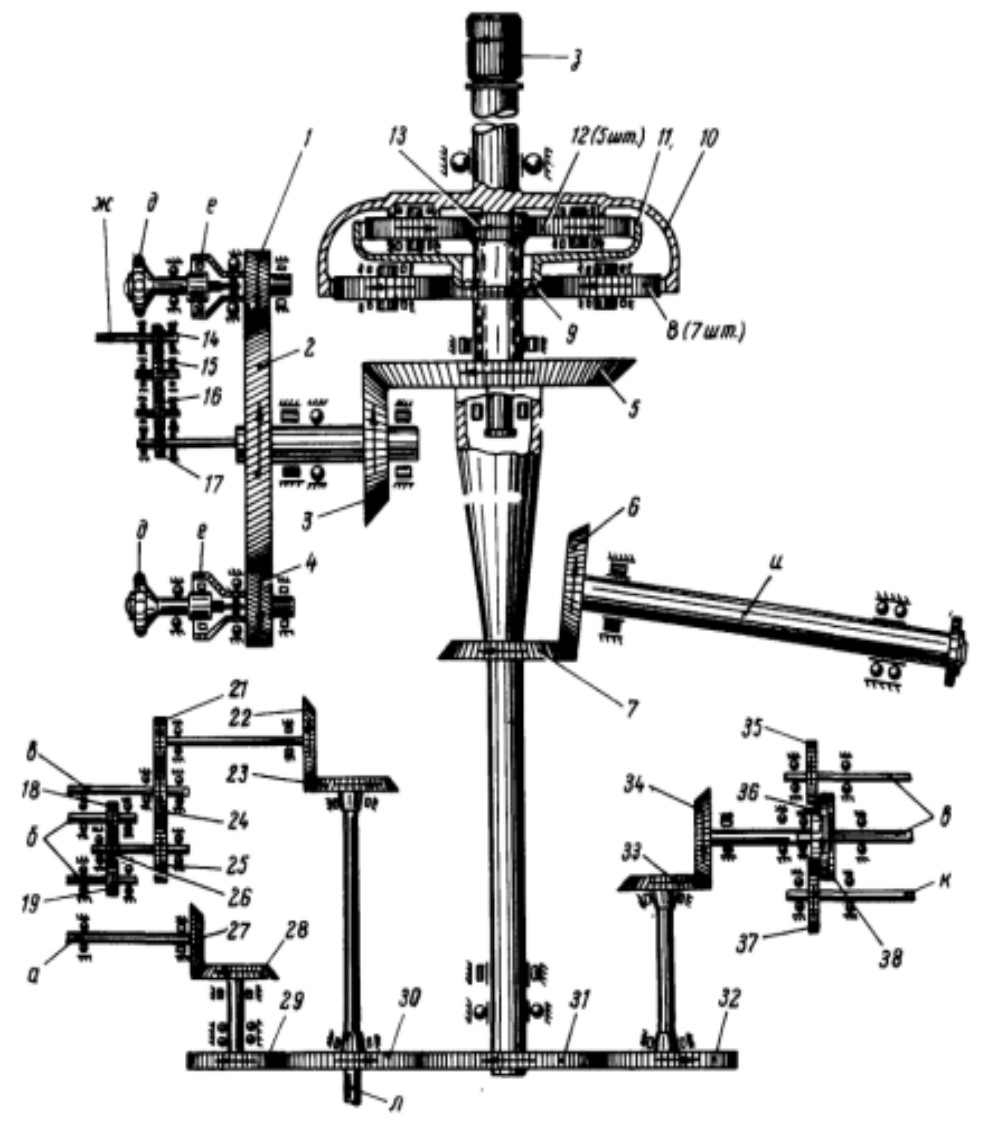

\begin{tabular}{|l|l|l|l|l|l|l|l|l|l|l|l|l|l|l|l|l|l|}
\hline № шестерні & 1 & 2 & 3 & 4 & 5 & 6 & 7 & 8 & 9 & 10 & 11 & 12 & 13 & 14 & 15 & 16 & 17 \\
\hline Число зубців & 33 & 95 & 31 & 33 & 66 & 31 & 41 & 29 & 48 & 103 & 69 & 29 & 31 & 27 & 45 & 45 & 39 \\
\hline № шестерні & 18 & 19 & 20 & 21 & 22 & 23 & 24 & 25 & 26 & 27 & 28 & 29 & 30 & 31 & 32 & 33 & 34 \\
\hline Число зубців & 27 & 27 & 25 & 32 & 24 & 29 & 47 & 48 & 27 & 19 & 41 & 39 & 49 & 74 & 49 & 29 & 24 \\
\hline № шестерні & 35 & 36 & 37 & 38 & & & & & & & & & & & & & \\
\hline Число зубців & 47 & 32 & 57 & 47 & & & & & & & & & & & & & \\
\hline
\end{tabular}

$a$ - привод до генератора; $\sigma$ - привод до тахометра; в - привод до шестеренного насосу НШ39-М; $\partial$ - увід вала двигуна; $e$ - муфта вільного ходу; ж - привод до вентилятора; 3 - привод до несучого гвинта; $u$ - привод до хвостового вала трансмісії; $\kappa$ - привод до повітряного компресора АК-50Т1; л-привод до маслонасосу

Рис. 1. Кінематична схема головного редуктора ВР-8А

По умовах роботи вертольота можуть бути реалізовані дві ситуації загального експлуатаційного навантаження вертольотних систем (рис. 2) [8].

В одному випадку вертоліт перелітає з вантажем і повертається без нього, не здійснюючи посадки після звільнення від вантажу. В іншому випадку має місце переліт 3 вантажем, в одному та іншому напрямку зі звільненням від нього під час посадки вертольота. Обидві ситуації мають свої особливості по пошкоджуваності матеріалу зубчастих коліс за повний цикл навантаження.

Особливості роботи редукторів і різні умови навантаження зубчастих коліс за політ не дозволяють однозначно виявляти домінуючий цикл навантаження для визначення ресурсу за критерієм недопущення їх руйнування, що призводить до втрати керованості вертольотом у польоті. Отримана інформація про умови навантаження зубчастих коліс під час виникаючих експлуатаційних руйнувань дозволяє встановити еквіваленти руйнівної дії навантажень під час роботи вертольота. Ця інформація необхідна не тільки для експертних досліджень причин руйнування зубчастих коліс, аналізу закономірностей їх навантаження в польоті, але вона може бути використана також під час вирішення питання про продовження терміну їх служби після напрацювання $10^{9}-10^{10}$ циклів [8]. 
$a$

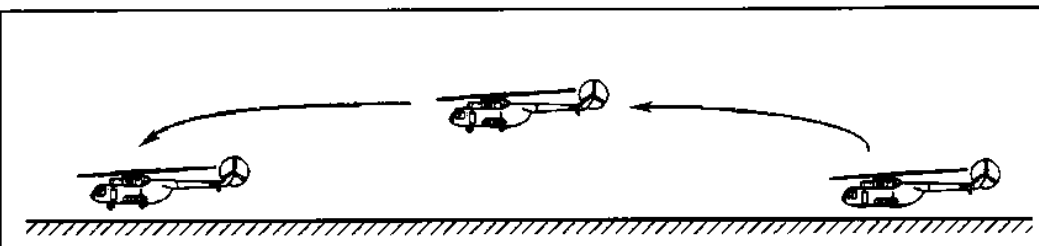

$\sigma$

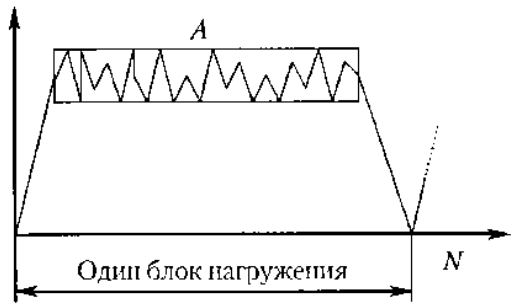

6

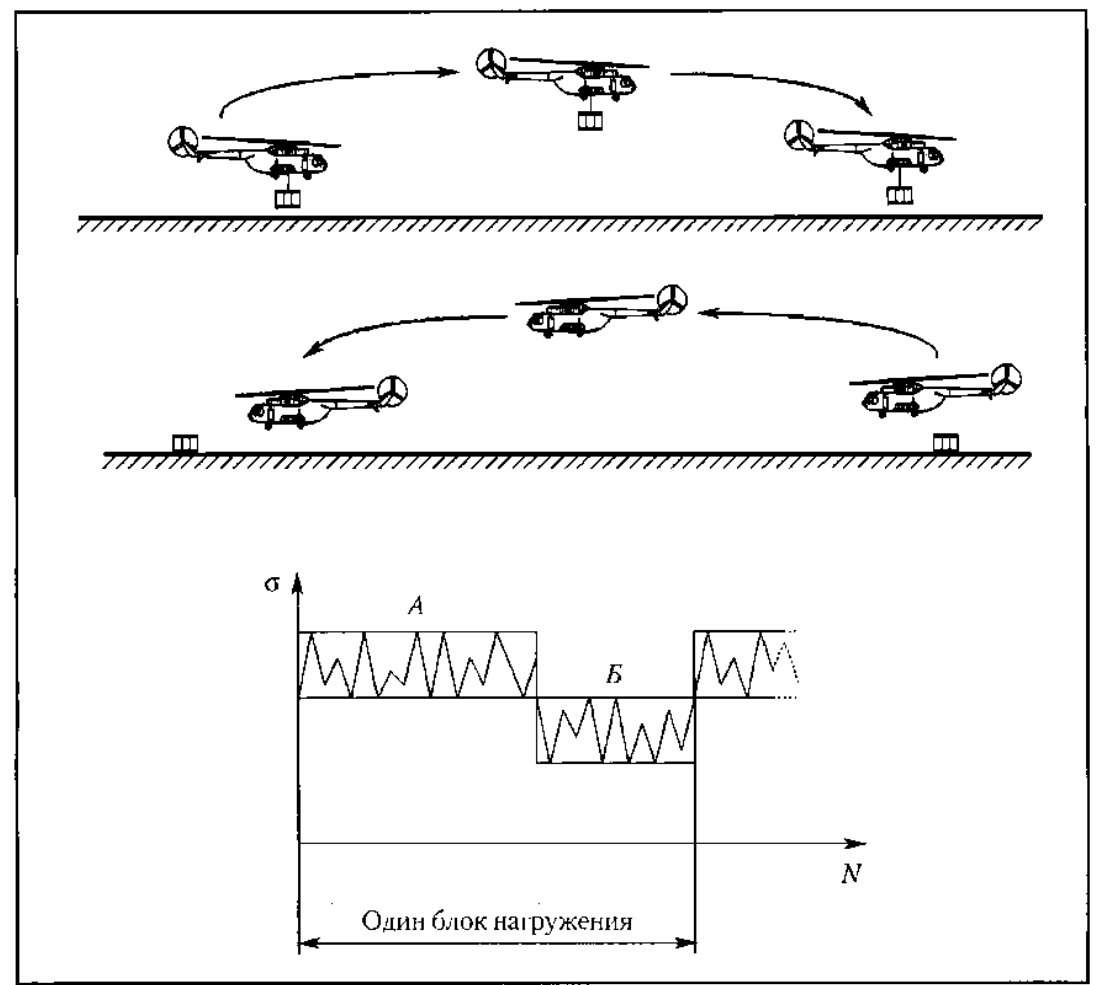

Рис. 2. Схема двох блоків циклічного навантаження вертольота при двох варіантах його роботи: а) перевезення вантажу з посадкою і б) без посадки

Динамічні навантаження в зачепленні евольвентних зубчастих коліс. Зачеплення зубчастих коліс в редукторах і трансмісіях спричиняють збурення динамічних навантажень $\mathrm{i}$ високочастотних вібрацій. На рис. 3 представлені динаміка і схеми руху зубців під час входу в зачеплення і виходу з нього $[9,10]$. Найбільш небезпечним для роботи зубчастого вінця $\epsilon$ крайковий контакт на вході в зачеплення 1,2 і виході з нього 3,4. Досвід свідчить, що в цих точках мають місце максимальні контактні напруження.

Динамічні навантаження під час входу в зачеплення і виходу з нього обчислюють окремо для точних і неточних під навантаженням зубчастих передач, причому передачі 3 $2,0<\varepsilon_{\alpha}<3,0$ розглядаються тільки як точні під навантаженням, тому що в іншому випадку їх застосування недоцільне.

Редуктори авіаційної техніки зазнають у польоті багаточастотне вібраційне навантаження в результаті багаточисельних взаємодій зубчастих коліс різних ступенів 3 різними швидкостями їх обертання. Зубчасті колеса в експлуатації редукторів, зокрема 
вертольотів, зазнають багатокомпонентне різночастотне навантаження при основній частоті від обертання колеса в декілька тисяч обертів за хвилину. Існуючі вібрації можуть породжувати коливання дисків зубчастих коліс, що призводить до виникнення багатоциклової втоми і швидкого вичерпання дисками їх довговічності.

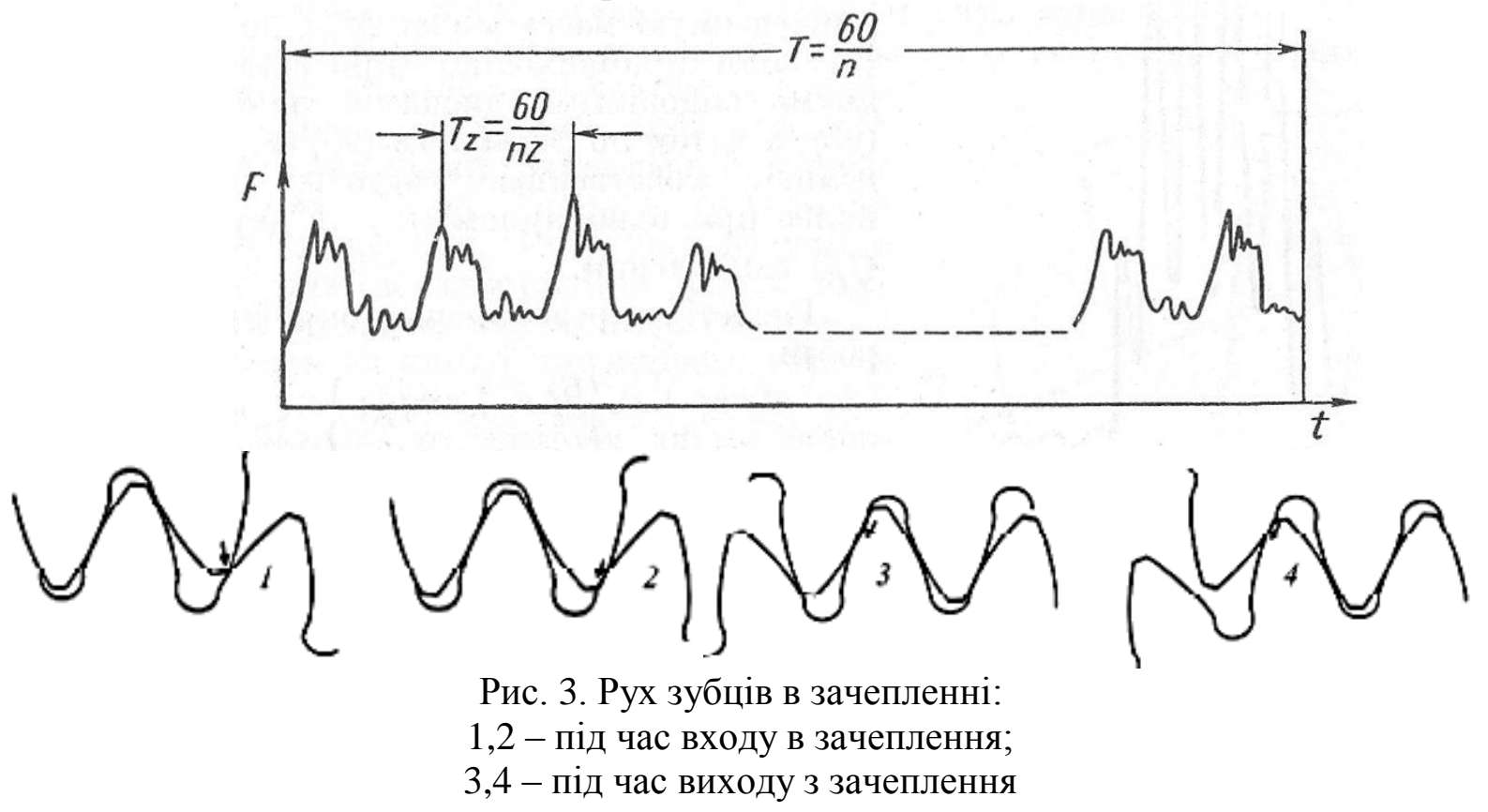

Присутність в зубчастому зачепленні широкого спектру рівнів і частот коливань призводить до того, що поза основною частотою навантаження зуба за кожен оберт колеса, може бути реалізоване додаткове його навантаження 3 різною моделюючою частотою i змінною амплітудою (рис. 4 ) [11].

Зубчасті колеса вертольота Ми-8 працюють при частоті 4200 хв$^{-1}$. Кожен зуб колеса зазнає контакту з двома сусідніми меншими за розміром колесами і тому за один оберт колесо входить 2 рази в контактне зачеплення. У зв'язку з цим частота навантаження кожного зубчастого колеса від одиничного акту навантаження складає 8340 цикл/хв.

Збудження резонансних згинальних вібрацій коліс викликається динамічними навантаженнями в зубчастому зачепленні, джерелом яких є крутильні коливання зубчастих приводів під час обертання коліс. Особливо небезпечні підвищені динамічні навантаження в зачепленні, зумовлені резонансними крутильними коливаннями зубчастих приводів.

Найбільш небезпечні високочастотні крутильні коливання 3 частотою зубців і кратною їй гармонікою. Основним джерелом таких коливань $є$ різна жорсткість зубців, що знаходяться в зачепленні [11].

Високочастотні крутильні коливання коліс підсилюються внаслідок циклічних похибок виготовлення зубців і складання коліс, що особливо позначається на роботі конічних коліс. Динамічні навантаження в зубчастому зачепленні, зумовлені крутильними коливаннями коліс, підсилюються поперечними коливаннями їх за наявності податливих валів і опор [11].

Параметричні резонансні коливання є джерелом підвищеного шуму в зубчастих передачах, інтенсивного зношування профілів зубців і т.д.

Більшість високонавантажених зубчастих передач мають перекриття в зачепленні $1<$ $\varepsilon_{\alpha}<2$, а сумарна жорсткість зубців у зоні двопарного зачеплення приблизно в 1,75 рази вище жорсткості однопарного зачеплення. Вказана особливість в робочих умовах $\epsilon$ джерелом збудження параметричних коливань зубчастих коліс, а при деяких умовах найбільш небезпечних параметричних резонансних коливань [11]. Амплітуда параметричних 
коливань залежить від точності виготовлення та завантаження коліс робочим моментом $\mathrm{i}$ обмежена величиною статичної деформації зубців.

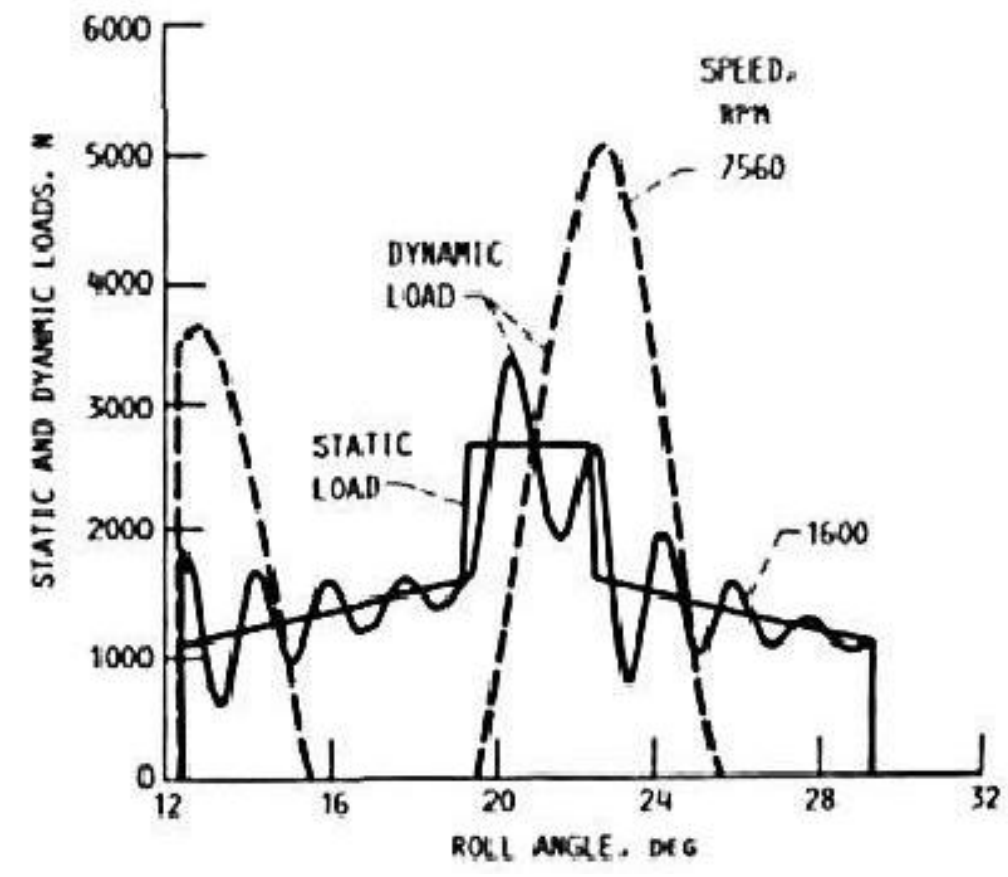

Рис. 4. Динамічні навантаження при різних швидкостях: модуль зачеплення $\mathrm{m}=3,18 \mathrm{MM}$;

кут тиску $\alpha=20^{0}$;

радіус початкового кола $\mathrm{r}=57,1 \mathrm{mм;}$

прикладене навантаження $\mathrm{F}=2760 \mathrm{H}$ [12]

Вібрації авіаційного редуктора значної інтенсивності мають механічне походження і проявляються в широкому діапазоні частот. Джерелами цих вібрацій є обертові елементи кінематичного ланцюга редуктора. Спектр вібрацій містить велике число дискретних складових і в значній мірі визначається спектром погрішностей обертання елементів кінематичного ланцюга.

На рис. 5 показаний типовий спектр вібрацій вертольотного редуктора [1]. У його спектрі можна виділити роторні вібрації з частотою $f_{n}$ і вібрації, збуджувані зубчастими колесами та підшипниками з частотою $f_{z}$.

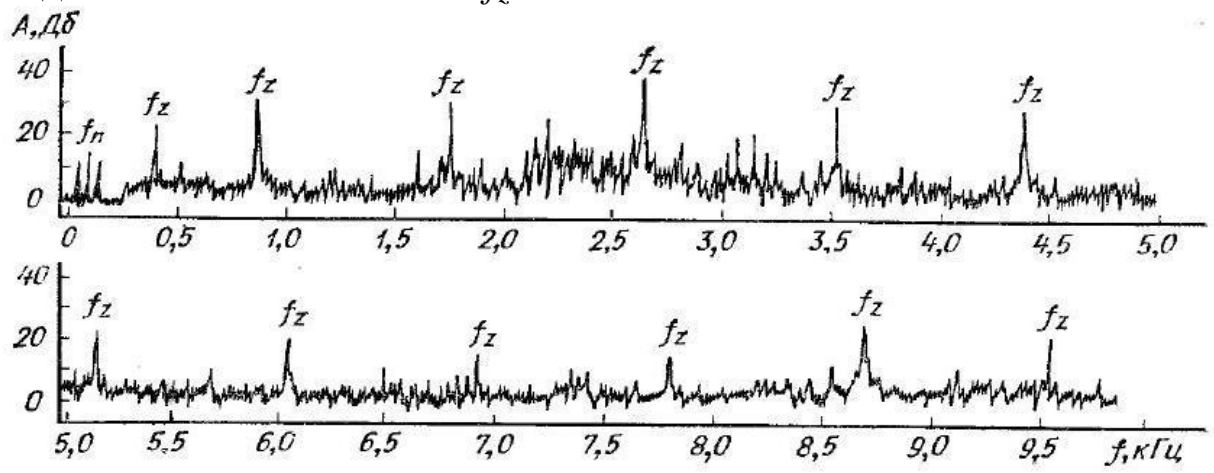

Рис. 5. Спектр вібрацій вертольотного редуктора

Роторні вібрації збуджуються в редукторі в результаті дисбалансів валів, підшипників і зубчастих коліс. Причиною цього є неоднорідність матеріалу, похибки геометрії, дефекти конструкції та монтажу, нерівномірність зношування деталей і послаблення їх спряжень в процесі експлуатації.

Зміна стану зубчастих передач у значній мірі відбивається на зміні як роторних гармонік $f_{n}$ i $n f_{n}$, так і гармонік з частотою зачеплення $f_{z}$ і $n f_{z}$, а також комбінованих частот $f=$ $f_{z} \pm n f_{n}$. Результати стежачого аналізу першої і другої гармонік від переспряження зубчастих 
коліс $z_{1}=22, z_{2}=41$ показує, що зношування робочих поверхонь викликає швидке зростання рівня вібрацій на частоті $f_{z}$ і менш інтенсивне - на частоті $2 f_{z}$. При виникненні заїдань, наряду зі зростанням вібрацій на частоті $f_{z}$, що триває, відбувається пришвидшене зростання інтенсивності складової $2 f_{z}$.

Максимуми в спектрі роторних вібрацій проявляються на частотах, що співпадають 3 частотами власних коливань зубчастих коліс.

Інтенсивність складових спектра вібрацій редуктора зростає 3 ростом частоти обертання та навантаження і залежить від стану його деталей.

У більшості випадків експлуатації спостерігалися руйнування зубчастих коліс головних редукторів ВР-8А, Р-7 і Р-26 вертольотів Ми-8, Ми-6 і Ка-26 відповідно, а також мав місце випадок руйнування зубчастих коліс хвостового редуктора вертольота Ми-6 (табл.1) [8].

Таблиця 1

Типи вертольотів, їх напрацювання і причини появи втомних тріщин в зубчастих колесах редуктора

\begin{tabular}{|c|c|c|c|c|}
\hline $\begin{array}{c}\text { № } \\
\text { п/п }\end{array}$ & $\begin{array}{c}\text { Тип } \\
\text { вертольоту }\end{array}$ & $\begin{array}{c}\text { Напрацювання, } \\
\text { год. / } \\
\text { п.ос. ремонту }\end{array}$ & Вид пошкодження & $\begin{array}{c}\text { Розмір } \\
\text { осердку, мм }\end{array}$ \\
\hline 1 & Ми-8 & $4486 / 18$ & Статична кутова тріщина & 4 \\
\hline 2 & Ми-8 & $6242 / 73$ & Статична наскрізна тріщина & 2 \\
\hline 3 & Ми-8 & $6686 / 458$ & Статична тріщина від отвору & 2,5 \\
\hline 4 & Ми-8 & $5109 / 918$ & Окисні пліни в центрі зуба & - \\
\hline 5 & Ми-8 МТВ & 740 & Окисні пліни & - \\
\hline 6 & Ми-6 & $1241 / 324$ & Втомне руйнування шліців & 1,8 \\
\hline 7 & Ми-6 & $3662 / 353$ & Втомне руйнування шліців & 1,4 \\
\hline 8 & Ми-6 & $4499 / 511$ & Втомне руйнування шліців & 1,1 \\
\hline 9 & Ми-6 & $5850 / 875$ & Втомне руйнування шліців & \\
\hline 10 & Ка-32А(А11) & $130,170,389 / 73$ & Втомне викришування & \\
\hline
\end{tabular}

У таблиці 2 наведені узагальні результати кількісного фрактографічного дослідження зубчастих коліс редукторів вертольотів Ми-8, Ми-6 і Ка-26 з різним типом зубчастого зачеплення, руйнування яких мало місце під час польоту за наявності попередніх пошкоджень матеріалу на стадії виробництва зубчастих коліс і в процесі їх експлуатації (табл. 2) [7,8].

Таблиця 2

Параметри деяких зубчастих коліс, втомні руйнування яких мали місце під час експлуатації

\begin{tabular}{|c|c|c|c|c|}
\hline Параметри & $\begin{array}{c}\text { Спіральне } \\
\text { зубчасте } \\
\text { колесо } \\
\text { першої } \\
\text { ступені } \\
\text { редуктора } \\
\text { Р-7 }\end{array}$ & $\begin{array}{c}\text { Ведуче } \\
\text { гелікоїдальне } \\
\text { зубчасте } \\
\text { колесо першої } \\
\text { ступені } \\
\text { редуктора } \\
\text { ВР-8А }\end{array}$ & $\begin{array}{c}\text { Ведене } \\
\text { колесо } \\
\text { першої } \\
\text { ступені } \\
\text { редуктора } \\
\text { Р-26 }\end{array}$ & $\begin{array}{c}\text { Ведене } \\
\text { спіральне } \\
\text { колесо } \\
\text { рестовторо } \\
\text { вертольоту } \\
\text { Ми-6 }\end{array}$ \\
\hline Число зубців & 28 & 95 & 32 & 21 \\
\hline Модуль, мм & 6,5 & 4,5 & 6 & 7 \\
\hline Діаметр кола колеса, мм & 182 & 454 & 192 & 147 \\
\hline Частота обертання колеса, хв & 8300 & 4200 & 865 & 2000 \\
\hline Обертовий момент, Н·м & 2370 & 2510 & 2670 & 3860 \\
\hline Час напрацювання між & 1000 & 1000 & 500 & 1000 \\
\hline ремонтами, год. & & & & \\
\hline
\end{tabular}


При напрацюванні редуктора в експлуатації більше 10000 годин число циклів навантаження кожного зуба колеса за умови його входження в контакт за кожний оберт складає $10^{9}$ циклів. Під час роботи зубчастих передач у складі редукторів вертольотів Ми-8 та їх модифікацій виникають втомні руйнування зубчастих коліс по ободу. Такі руйнування зумовлені згинальними резонансними коливаннями коліс у робочому діапазоні частоти обертання. Схильність до руйнування коліс від резонансних вібрацій притаманна більше всього колесам конічних передач під час коливання їх в осьовому напрямку. Втомне руйнування конічного колеса, як правило, починається по ободу в основі зуба, і далі тріщина розвивається в колесі по формі його коливань. При великих резонансних напруженнях в радіальному напрямку можливий початок руйнування у маточини. Втомні руйнування від резонансних вібрацій можливі також у циліндричних зубчастих коліс під час їх коливань в радіальному напрямку як маси обода колеса на пружній основі - діафрагмі колеса.

У зв'язку з відмовами редукторів з причини руйнування їх зубчастих коліс виникла необхідність пошуку підходів і шляхів вирішення задачі кількісної оцінки довготривалості зростання тріщин у зубчастих колесах під час проведення розслідувань тяжких льотних подій. Довготривалість експлуатації між двома сусідніми оглядами редуктора не повинна перевищувати час росту тріщини до критичних розмірів.

Всі експлуатаційні руйнування зубчастих коліс першої ступені редукторів ВР-8А вертольота Ми-8, що мали місце, булі пов'язані з наявністю в них дефектів матеріалу. Принципова різниця руйнувань полягала лише в тому, що попередньо зони дефектів матеріалу мали різні місця розташування, різну протяжність і форму. У двох випадках руйнування осередку розташовувались в частині ободу колеса біля зубців, а в одному випадку осередка розташовувалося у технологічного отвору недалеко від центрального отвору колеса (рис.6) [8].

При цьому фізична сутність виникаючих пошкоджень і кінетика виникнення від них і розвитку подальших втомних тріщин були подібні.

Під час контакту зубців виникають розтягуючи напруження. Стосовно зубчастих коліс 3 напрацюванням в експлуатації 9313 годин втомна тріщина в процесі свого розвитку, перетнула обод зубчастого вінця, далі вона увійшла в стінку діафрагми, і від цієї первинної втомної тріщини здійснилося відгалуження вторинної тріщини, як показано стрілками на рис. 6. Ця тріщина повернулася до ободу, в результаті чого від зубчастого колеса відділився обломок зубчастого вінця, що містив шість зубців.

Контактні руйнування зубців $\epsilon$ основною причиною відмов швидкохідних зубчастих коліс в добре змащуваних закритих передачах. Під час ремонту авіаційних двигунів із загальної кількості відбракованих зубчастих коліс до 85\% складають колеса, відбраковані по причині контактних руйнувань зубців: вищерблювання і відшарування.

На рис. 7 представленипй основний дефект косозубих шестерен у вигляді вищерблювання. Пошкоджені ділянки розташовані на робочій стороні профілів зубців вздовж лінії крайкового контакту у торцевій поверхні [10].

Металографічні дослідження за допомогою оптичного мікроскопу Axiovert 40 MAT, оснащеного фотокамерою і програмою аналізу зображень Thixomet PRO, показали, що на мікрошліфах, виготовлених з розрізаних у поперечному перерізі дефектних зубців, яскраво виражені лінії підповерхових тріщин вздовж евольвенти по робочій стороні, які виникають від ділянки вищерблень (рис. 8) [10].

Основними причинами контактних руйнувань зубців $є$ : концентрація навантаження на довжину і профіль зубців, наявність залишкових розтягуючих напружень на робочих поверхнях зубців, несприятливі експлуатаційні пошкодження профілів зубців і несприятливі впливи на зубці змащувальної рідини. 

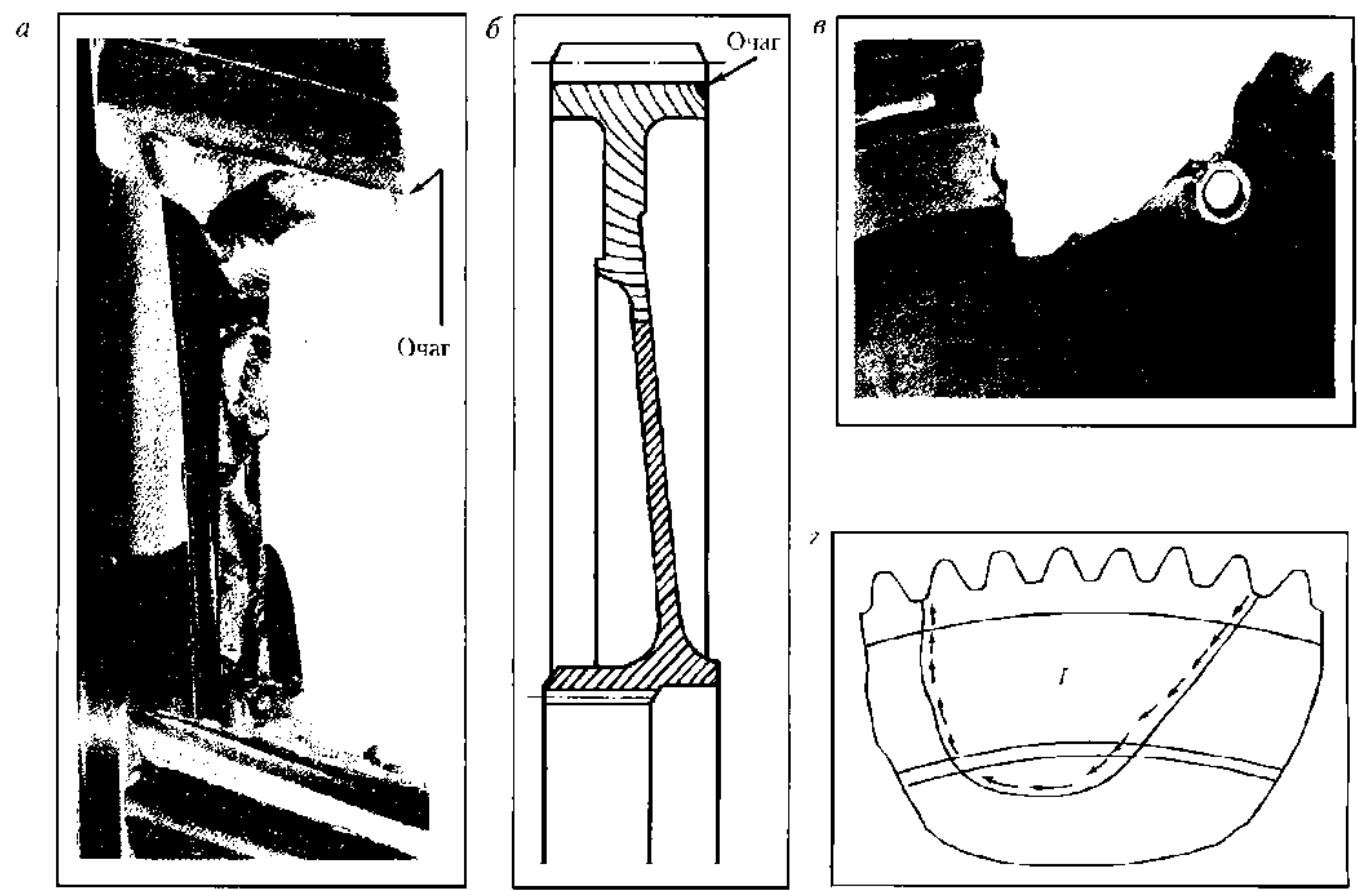

Рис. 6. Загальний вигляд (а) зруйнованого (в) зубчастого колеса вертольота Ми-8 (б), схема розповсюдження в ньому тріщини (г)
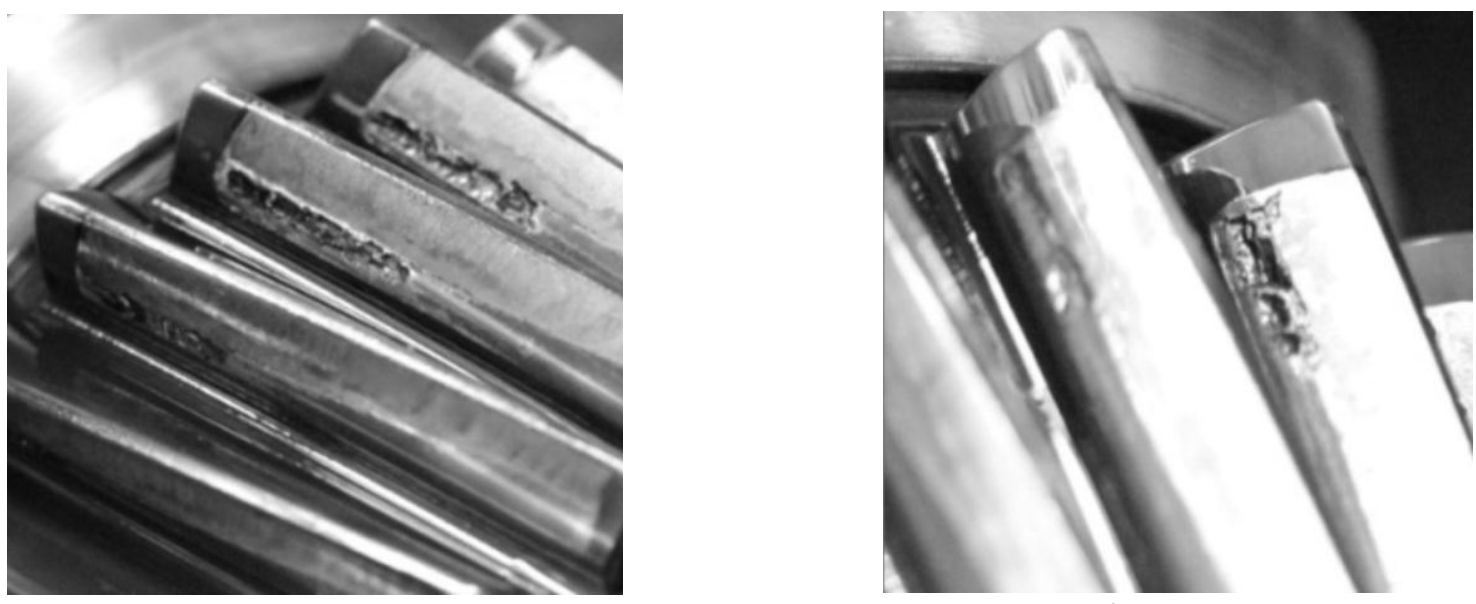

Рис. 7. Вищерблювання зубчастих коліс

Висновки. Для авіаційних зубчастих передач характерний розподіл навантаження між спряженими парами зубців. Найбільш небезпечним для роботи зубчастого вінця $\epsilon$ крайковий контакт на вході в зачеплення і виході з нього. Досвід свідчить, що в цих точках мають місце максимальні контактні напруження.

Редуктори авіаційної техніки, зокрема вертольотів, зазнають у польоті багаточастотне вібраційне навантаження в результаті багаточисельних взаємодій зубчастих коліс різних ступенів 3 різними швидкостями їх обертання. Існуючі вібрації можуть породжувати коливання дисків коліс, що призводить до виникнення багатоциклової втоми і швидкого вичерпання дисками їх довговічності.

Збудження резонансних згинальних вібрацій коліс викликається динамічними навантаженнями в зубчастому зачепленні, джерелом яких є крутильні коливання зубчастих приводів під час обертання коліс. Особливо небезпечні підвищені динамічні навантаження в зачепленні, зумовлені резонансними крутильними і параметричними коливаннями зубчастих приводів. 

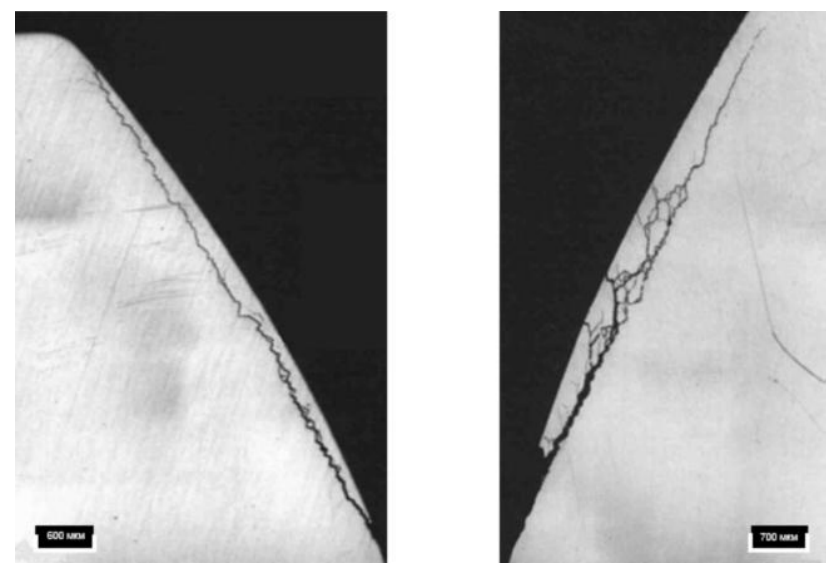

ISSN 2706-7386

Рис. 8. Мікрошліфи робочої сторони профілів зубців

Під час роботи зубчастих передач у складі редукторів вертольотів Ми-8, їх модифікацій та ін. виникають втомні руйнування зубчастих коліс на ободі. Такі руйнування зумовлені згинальними резонансними коливаннями коліс у робочому діапазоні частоти обертання.

Контактні руйнування зубців є основною причиною відмов швидкохідних зубчастих коліс в добре змащуваних закритих передачах. Під час ремонту авіаційних двигунів із загальної кількості відбракованих зубчастих коліс до 85\% складають колеса, відбраковані 3 причини контактних руйнувань зубців: вищерблювання і відшарування.

\section{СПИСОК ЛІТЕРАТУРИ}

1. Авиационные зубчатые передачи и редукторы; под ред. Э.Б. Вулгакова. - М.: Машиностроение, 1982. - 375 с.

2. Положение об установлении и увеличении ресурсов агрегатам трансмиссии вертолётов гражданской авиации. - Москва:. - 2004. - 30 с.

3. Оценка и обоснование продления ресурса элементов конструкций; Под ред. B.T. Трощенко. / Институт проблем прочности НАН Украины. - Киев, 2000. - Т. 1, 2.

4. Семенихин Р.Л. Экспериментально-теоретическая оценка ресурсоспособности элементов вертолётных конструкций: диссертация канд. техн. наук. - М., $2014-134$ с.

5. Шаповалов О. Конструкції, кінематичні схеми та технічні характеристики вертольотних редукторів: науковий журнал. / О. Шаповалов, Д. Колесник, О. Пилипенко. // Технічні науки та технології. - Чернігів, 2018. - №2(12). - С. 34-48.

6. Данилов В.А. Вертолёт Ми-8. Устройство и техническое обслуживание. / В.А. Данилов. - М.: Транспорт, 1988. -278 с.

7. Вертолёт Ми-8. Техническое описание. Книга II. Конструкция. Внешторгиздат. Изд. № 136423. Типография ВТИ. Зак. № 4575. - 189 с.

8. Шанявский А.А. Безопасное усталостное разрушение элементов авиаконструкций. Синергетика в инженерных приложениях: монография. / А.А. Шанявский. - Уфа, 2003. -804 c.

9. Биргер И.А. Расчёты на прочность деталей машин: справочник. / И.А. Биргер, Б.Ф. Шорр, Г.Б. Иосилевич. - М.: Машиностроение, 1979. - 702 с.

10. Кобелева К.В. Обзор методов повышения долговечности авиационных зубчатых передач: вестник ПНИПУ. / К.В. Кобелева, В.Р. Туктамышев. / Аэрокосмическая техника. - Пермь, 2017. - № 50. - С. 128-138.

11. Hsiang-Hsi (Edward) Lin, Ronald L. Huston, John J. Coy. Dynamic Loads in Parallel Shaft Transmissions. Part I, II. Published in ASMJ Journal of Mechanisms, Transmissions and Automation in Design. - Vol 110. - No 2. - June, 1988. - pp. 221-229, and as NASA Technical Memorandum 100280, 100281 and AVSCOM T.M. 87-C-2, C-3. Reprinted with permission. 


\section{Пилипенко Олег Іванович}

доктор технічних наук, професор, провідний науковий співробітник Державного науководослідного інституту випробувань i сертифікації озброєння та військової техніки, Чернігів, Україна

http//orcid.org/ 0000-0003-0590-0107

E-mail: opilip@ukr.net

Колесник Денис Миколайович - начальник відділення Державного науково-дослідного інституту випробувань і сертифікації озброєння та військової техніки, Чернігів, Україна

http//orcid.org/ 0000-0001-8833-570X

E-mail: denis1971@ukr.net

Березняк Анатолій Миколаєвич - старший науковий співробітник Державного науководослідного інституту випробувань i сертифікації озброєння та військової техніки, Чернігів, Україна

http//orcid.org/ 0000-0003-4081-9152

E-mail: berezniak80@ukr.net

\section{Шоха Вадим Миколайович}

начальник відділу Державного науководослідного інституту випробувань i сертифікації озброєння та військової техніки, Чернігів, Україна http//orcid.org/0000-0003-1950-0868 +38 (093) 316-77-16

\section{Oleg Pilipenko}

Doctor of Technical Sciences, Professor, Lead Researcher of State Scientific Research Institute of Armament and Military Equipment Testing and Certification, Chernihiv, Ukraine http//orcid.org/0000-0003-0590-0107

E-mail: opilip@ukr.net

\section{Denis Kolesnik}

Chief of Section of State Scientific Research Institute of Armament and Military Equipment Testing and Certification, Chernihiv, Ukraine http//orcid.org/0000-0001-8833-570X

E-mail: denis1971@ukr.net

\section{Anatoli Berezniak}

Senior Researcher of State Scientific Research Institute of Armament and Military Equipment Testing and Certification, Chernihiv, Ukraine http//orcid.org/0000-0003-4081-9152

E-mail: berezniak80@ukr.net

\section{Vadym Shokha}

Chief of Section of State Scientific Research Institute of Armament and Military Equipment Testing and Certification, Chernihiv, Ukraine http//orcid.org/0000-0003-1950-0868 +38 (093) 316-77-16

\section{VIBRATORY LOADING AND DESTRUCTION OF HELICOPTER'S REDUCTION TRAINS O. Pilipenko, D. Kolesnik, A. Berezniak, V. Shokha}

The helicopter reducers undergo in-flight multifrequency vibratory loading as a result of the numerous cooperating of gear-wheels of the different degrees with different speeds of rotation. Gear-wheels used in reducers, in particular on helicopters, are tested by multicomponent different-frequency loadings at fundamental frequency of the rotation of wheel at a few thousand round/min. Existent vibrations can generate the oscillations of disks of reduction trainss, that conduces to the appear of multicyclic fatigue and rapid decrease of the disks longevity.

Vibratory loading of helicopter's high-speed reduction trains on the takeoff and cruiser modes of exploitation, load distribution between teeth in the zone of the multiple-tooth engagement, dynamic loading of engaged gear-wheels and their damage and destruction are considered in the article.

The most dangerous high-frequency turning vibrations coincide with frequency of teeth and multiple harmonics. The main source of such vibrations is different rigidity of engaged teeth.

The high-frequency turning vibrations of wheels increase as a result of cyclic errors of making of teeth and assemble of wheels that especially affects work of conical wheels. The dynamic loading in the gear engagement, predefined by the turning vibrations of wheels, increase by their transversal vibrations in presence of nonrigid shafts and supports.

For the aviation trains there is a typical distribution of load between the pairs of gears. The most dangerous thing for the functioning of ring gear is edge contact during initial clutching and subsequent declutching. Experience makes it plain that maximal contact stresses take place at these points.

During functioning of Mi-8 helicoptes (their modifications) reduction trains, there are fatigue damages of gearwheels on a rim. Such damages are predefined by the flexing resonance vibrations of wheels in the working range of frequency of rotation.

Contact damages of teeth are the principal cause of failure of high-speed gear-wheels in the well-oiled closed transmissions. During repair of aviation engines from the general amount of discarded gear-wheels up to $85 \%$ constitute a part of wheels which were discarded with the reason of contact destructions of teeth: cutting wear and delamination.

Keywords: helicopter reduction trains, vibratory loading, damages. 